\title{
Risk assessment related to the choice of contractors performing the job
}

\author{
Iuliia Valitova ${ }^{1, *}$, Tatiana Trofimova ${ }^{1}$, Tatiana Simankina ${ }^{1}$ and Elena Stein ${ }^{2}$ \\ ${ }^{1}$ Peter the Great St. Petersburg Polytechnic University, 29 Politechnicheskaya St., St. Petersburg, \\ 195251, Russia \\ ${ }^{2}$ Moscow State University of Civil Engineering, Yaroslavskoe shosse, 26, Moscow, 129337, Russia
}

\begin{abstract}
Construction and investment projects inherent risks in an extremely wide range of human activity fields. An analysis of risks from the viewpoint of management and mitigation is conducted in this article. Particular attention is paid to the analysis of risk events related to the choice of an unqualified contractors performing the job. The compliance of duration implementation project, the budget amount, and the quality of performed work depend on this choice. The contractors risk assessment methods analysis showed that besides the overall criterion for all methods connected to the cost of work it is vital to take into account the qualifications, reputation, material and technical base of a contractor, the time and quality of the work performed previously. Existing methods with criteria of the choice of contractors performing the job are considered. The universal methodology with a set of criteria that satisfies all construction process participants, and based on publicly accessible information about companies and their experience is essential.
\end{abstract}

\section{Introduction}

The construction field is a social material and production system. This system operates in risk and uncertainty conditions, determined by a huge amount of factors. The main uncertainties are related to the openness of construction products to the external environment of consumers in the form of the most economy sectors. Uncertainties also arise due to the state of the environment, characterized by the development of the state economy and a significant relationship with the investment opportunities of construction projects customers. [1]

An extremely wide range of human activity spheres risks are inherent in investment and construction projects including economic, political, technical, legal, natural, operational risks, etc. Many authors investigate the topic of construction projects risks and suggest different versions of risk classifications. Risks can be divided into external and internal from the viewpoint of risk management and minimization (Fig. 1).

The system stability is exposed to significant risks due to economic, technological and social uncertainties. As a whole, risks assessment related to this problems, and ability to develop measures to avoid risks are key factors of system stability and existence. [2]

\footnotetext{
* Corresponding author: valitovajulian@gmail.com
} 


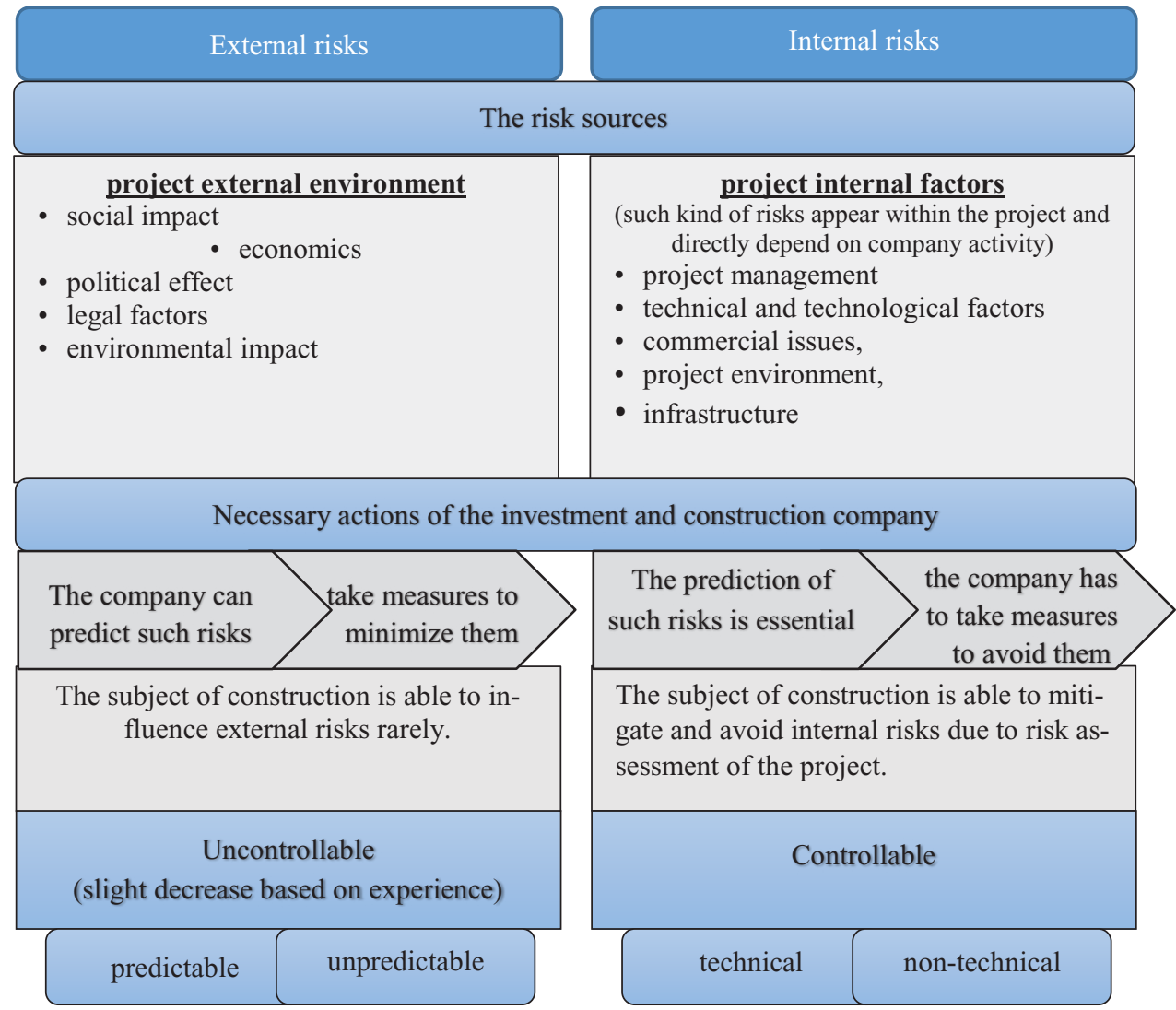

Fig. 1. Risks classification from the viewpoint of risk management.

The percentage of suspended construction projects in 2016 amounted to 13\% (Fig.2.) [3].

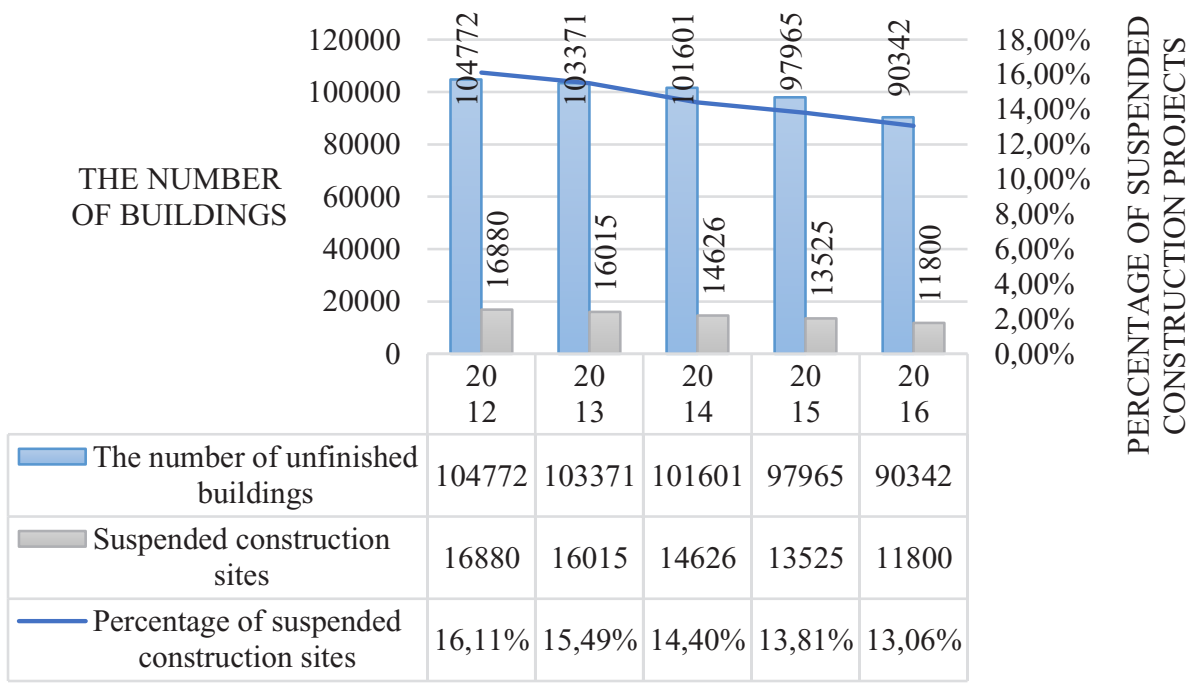

Fig. 2. Annual statistics on the number of suspended and unfinished construction projects and percentage of suspended construction sites in the Russian Federation. 
Statistics for the last 5 years show that the percentage of suspended construction projects decreases every year, but the problem of choosing a reliable protection scheme against risks related to the investment and construction projects implementation remains relevant. The main reason for suspension of buildings and structures construction is incorrect processes organization. Organizational risks are risks caused by shortcomings in the organization of working process at various planning and implementation stages of the investment and construction project. The most prevalent organizational risks include: errors detection in the project documentation, building materials supplying interruptions, delays due to poor-quality communications between the project participants, incomplete materials supplying, contract implementation disruptions, tender disruptions, financing delays of the project by investors, work implementation contract cancellation, materials supplying contract cancellation [4]. This circumstances lead to searching of economy ways among developers. Construction participants start using low-cost materials analogues, moreover, they attract unskilled labor.

\section{Materials and methods}

In the Russian Federation methodological and methodical materials on risk management of investment and construction projects are developed insufficiently. However, over time, significant practical steps are observed in this field. As practice and experience shows, risk assessment in large investment and construction companies is one of the main tasks during the project planning period. There are a lot of researchers insisting on the development of riskbased approach in construction industry. It could demonstrate project benefits and will ease construction process for all of the participants due to publicly accessible information about companies and their experience [5]. The opportunities offered by the organization's risk management process help manager to achieve profitability and efficiency targets, as well as to prevent the irrational usage of resources. The risk management process assists: to ensure an effective process of financial statements preparing, compliance with laws, regulations, and standards; to avoid reputation damage of the company and related consequences. Thus, a timely risk assessment process allows employees of the company to achieve project goals while avoiding miscalculations and incident $[6,7]$.

Construction risks arise as a result of facility construction and cause construction process deviation compared with the planned tasks [8]. Initially, it is necessary to select assessment criteria that allow to obtain reliable information about all the risks of the system elements then acquire the total risk result for each event. Each risk situation needs to be managed based on the results of the analysis. Risk management - a set of methods of analysis and neutralization of risk factors combined in the planning, monitoring and correction action system [1].

There are different risk assessment and management methods, each of them has positive and negative sides. Development of methodological instructions for risk management is a complex process that combines necessity to conduct classification of certifiers, certification systems and the companies themselves that are implementing the quality management system. That's procedure quite specific to the economy environment of the Russian Federation [9]. Risk assessment methods are divided into qualitative and quantitative. The qualitative analysis identifies the sources, causes and places of risk events. Quantitative analysis is a consequence of qualitative and allows to determine numerical values of risk factors fluctuations [11]. The choice of the estimation method is connected with the amount and reliability of the available information, planning level and the expediency of obtaining forecast information by formulating and researching complex economic and mathematical models [1, 12]. Economic analyses are essential from the viewpoint of planning of the sufficient funds. The management system cannot function without adequate cost-benefit analyses, it necessarily needs comparisons of the invested funds and the profits [13].

Consider the risk assessment related to the choice of contractors performing the job. 
One of the most important tender organizer functions is the right choice of construction participants for the property. In case of failure of the construction period, investors incur huge losses. In the implementation process of the investment and construction project, all participants are exposed to a significant number of risks. There are such risks related to the investor as dishonesty of the chosen developer, increase the duration of construction, change in interest loans rates. Risks of the developer are termination of investments; substandard performance of contractors works [14].

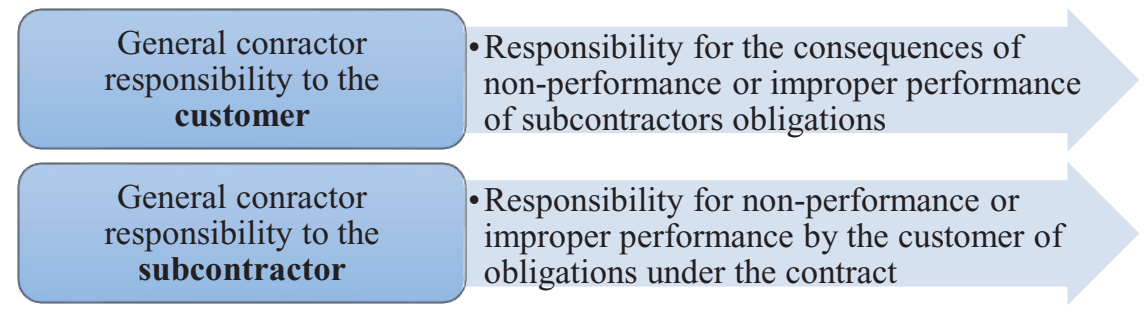

Fig. 3. General contractor responsibility to the customer and subcontractor.

Some construction participants, such as a developer, general contractor, designer, also bear a certain responsibility for their construction activities. The general contractor bears the greatest responsibility, compared to other construction participants [15]. The risks of the general contractor relate mainly to the construction and installation works execution. The responsibility of the general contractor to the customer and the subcontractor is shown in Fig.3. In Fig.4. the main responsibility areas of contractors are shown.

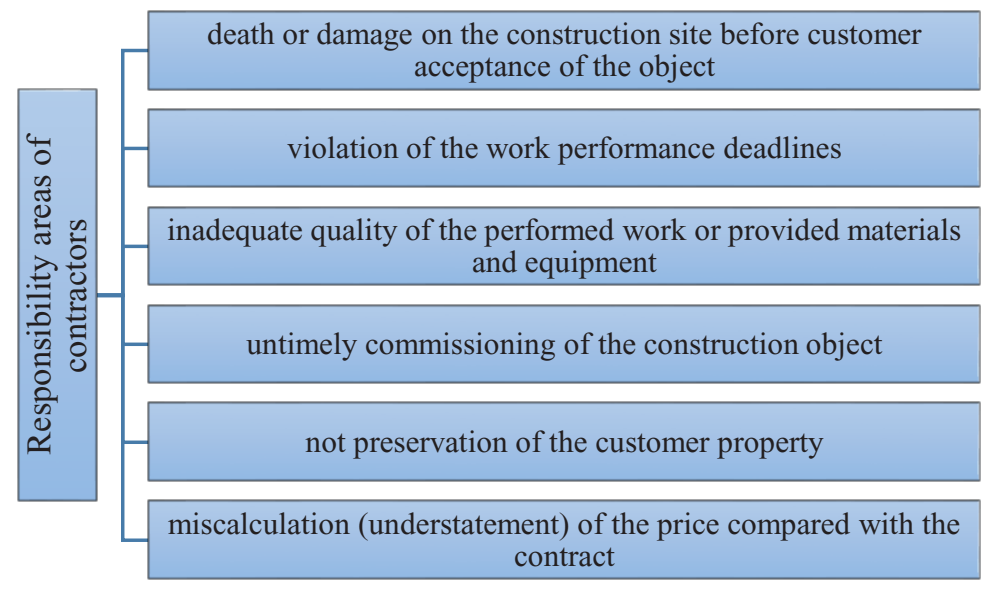

Fig. 4. Responsibility areas of contractors.

Thus, construction companies, which act as a contractor or general contractor, bear the greatest share of responsibility in the implementation of the construction project in comparison with other participants. Therefore, construction organizations should carefully approach the issue of selecting contractors and identifying and minimizing risks. The main task of the contractor is to maximize profits and minimize costs.

The main selecting contractors' criteria include:

- Contractor's price;

- Project implementation deadlines;

- Relevant qualifications;

- Material and technical base; 
- Warranty period of works execution;

- Confirmation of compliance with the deadlines for the commissioning of constructed facilities;

- The contractor's reputation (it is necessary to have positive feedback from the managers of previous facilities on the quality of work, and to have a minimum number of supervisory comments);

- Official registration in the territory of the Russian Federation;

- The organization must be registered and realize activity at least 3 years;

- The absence of debts to tax authorities;

- The absence of litigation in the last 3 years.

To date a large number of researches on the optimal choice of the contractor was conducted. The researches affecting on the construction industry are summarized in Table 1.

Table 1. Methods of choosing contractors.

\begin{tabular}{|c|c|c|c|}
\hline No & Methods & Description & Selection Criteria \\
\hline 1. & $\begin{array}{l}\text { A model of the contrac- } \\
\text { tor's business reputation } \\
\text { was created during the } \\
\text { construction of the build- } \\
\text { ing. }\end{array}$ & $\begin{array}{l}\text { The author applied the expert evaluation } \\
\text { apparatus of the factors levels and their } \\
\text { importance in the structure of business rep- } \\
\text { utation. A mathematical model of the com- } \\
\text { plex index of business reputation was cre- } \\
\text { ated [16]. }\end{array}$ & $\begin{array}{l}\text { Relevant qualifications, } \\
\text { material and technical } \\
\text { base, contractor's reputa- } \\
\text { tion, contractor's price, } \\
\text { warranty period of works } \\
\text { execution, terms of project } \\
\text { implementation, quality of } \\
\text { work performance. }\end{array}$ \\
\hline 2. & $\begin{array}{l}\text { The main procurement } \\
\text { development problems } \\
\text { of construction works in } \\
\text { the city order system are } \\
\text { determined and ways of } \\
\text { their solution are out- } \\
\text { lined. }\end{array}$ & $\begin{array}{l}\text { The following questions are considered in } \\
\text { the work: determination of the contractors } \\
\text { qualifications, organization and contract } \\
\text { tenders holding for state and municipal } \\
\text { purchases of construction products [17]. }\end{array}$ & $\begin{array}{l}\text { Relevant qualifications, } \\
\text { contractor's price, warranty } \\
\text { period of works execution, } \\
\text { terms of project implemen- } \\
\text { tation. }\end{array}$ \\
\hline 3. & $\begin{array}{l}\text { There are was developed } \\
\text { a program in which a } \\
\text { particular contractor is } \\
\text { given a number of "com- } \\
\text { petence questions". }\end{array}$ & $\begin{array}{l}\text { After answering a number of competence } \\
\text { questions for specific contractors, the ten- } \\
\text { der organizer receives an assessment for } \\
\text { this agent [18]. }\end{array}$ & $\begin{array}{l}\text { The work deals with soft- } \\
\text { ware packages developed } \\
\text { for the evaluation of con- } \\
\text { tractors, so there are not } \\
\text { specified selection criteria. }\end{array}$ \\
\hline 4. & $\begin{array}{l}\text { The method of automat- } \\
\text { ing the business process } \\
\text { of selecting a contractor } \\
\text { for a construction com- } \\
\text { pany using the COBRA } \\
++ \text { system was described } \\
\text { [19]. }\end{array}$ & $\begin{array}{l}\text { The "Cobra }++" \text { system allows to carry out } \\
\text { strategic planning, to plan the costs for the } \\
\text { project, to manage the cash flow, and to } \\
\text { analyze the actual output of the project. } \\
\text { Also, the software complex "Cobra }++" \text { al- } \\
\text { lows to monitor all processes of organiza- } \\
\text { tions and their departments in real time } \\
\text { and allows you to see at what stage the } \\
\text { task is being performed and with what in- } \\
\text { dicators the previous stages are completed. }\end{array}$ & $\begin{array}{l}\text { The work deals with soft- } \\
\text { ware packages developed } \\
\text { for the evaluation of con- } \\
\text { tractors, so there are not } \\
\text { specified selection criteria. }\end{array}$ \\
\hline 5. & $\begin{array}{l}\text { A scoring system to as- } \\
\text { sess the risks of choos- } \\
\text { ing a contractor was de- } \\
\text { veloped. }\end{array}$ & $\begin{array}{l}\text { The author develops a scoring system for } \\
\text { assessing the risks related on the selection } \\
\text { of contractors participating in the competi- } \\
\text { tion for the performance of a certain work } \\
\text { type using matrix mechanisms of inte- } \\
\text { grated assessment [20]. }\end{array}$ & $\begin{array}{c}\text { Relevant qualifications, } \\
\text { material and technical } \\
\text { base, contractor's price, } \\
\text { quality of work perfor- } \\
\text { mance. }\end{array}$ \\
\hline
\end{tabular}




\section{Conclusion}

Summing up the investigation, the following conclusions can be made:

1. The choice of a particular standard as the basis for establishing an effective risk management system within a particular enterprise is a significant problem. Investment and construction companies should clearly understand the requirements of each standard, and the practical application ways of adapted to company's parameters standards.

2. There is no universal methodology among existing methods of risk analysis that would give a comprehensive understanding of the risk. Qualitative methods are descriptive and highly subjective, quantitative methods are not always absolutely objective too.

3. The choice of application the risk analysis method mostly depends on: the purpose of the risk analysis, time and financial capabilities of the company, the competence of the expert conducting the assessment.

4. The choice of an unprofessional and low-skilled contractor is one of the most common risk events. The compliance of duration implementation project, the budget amount, and the quality of performed work depend on this choice.

5. There are certain criteria for the choice of contractors performing the job in each considered methods. The establishment of a universal methodology is required. This methodology should be a set of criteria that satisfies all construction process participants.

\section{References}

1. S. Korol', Modern Management Technology, 2(62) (2016)

2. M. Assayra, NAUKOVEDENIE 2, 1-7 (2016)

3. http://www.gks.ru/

4. E. Okhvatova, S. Belyakov, Real estate: economics, management 1, 34-38 (2017)

5. K. Pykhtin, T. Simankina, V. Sharmanov, A. Kopytova, IOP Conf. Series: Earth and Environmental Science 90, 012065 (2017)

6. https://www.coso.org/documents/coso_ERM_ExecutiveSummary_Russian.pdf

7. Baranov, International standards for risk management: not a single Basel, Rynok Tsennykh Bumag 5, 23-33 (2015)

8. Shnyrova, Modern methods of risk assessment in construction, Innovatsionnaya nauka 12, 152-153 (2015)

9. S. Lukichev, M. Romanovich, Procedia Engineering 165, 1717-1721 (2016)

10. N. Sergeeva, K. Koryakina, Novaya nauka: opyt, traditsii, innovatsii 1-1(123), 267-270 (2017)

11. R. Abakumov, E. Grishchenko, L. Strekozova, Innovatsionnaya nauka 5, 10-12 (2016)

12. L. Aglyamova, N. Mostovskiy, P. Mostovskaya, T. Simankina, Nauka i obrazovanie: novoye vremya 3 (20), 219-228 (2017)

13. S. Ognjenovic, A. Ishkov, D. Cvetkovic, D. Peric, M. Romanovich, Procedia Engineering 165, 954-959 (2016)

14. A. Badalova, Vestnik MGSU 6, 22-28 (2011)

15. Budzulyak, A. Apostolov, N. Seleznev, L. Moiseev, N. Alekseenko, Gas industry 4, $12-$ 16 (2015)

16. T. Soldatenko, Construction of Unique Buildings and Structures 12 (27), 7-23 (2014)

17. M. Demidenko, Vestnik grazhdanskih inzhenerov 2(55), 298-305 (2016) 
18. A. Sobah, Springer Science+Business Media New York, 261-270 (2004)

19. Zh. Dorokhova, Science and business: development ways 2 (32), 46-51 (2014)

20. T. Nakashidze, Development and research of methods for assessing the risks of choosing a contractor for construction and installation works, Master Thesis (2016) 